$\begin{array}{rr}\text { JURNAL } & \text { Volume } 13, \text { Nomor 5, September } 2017 \\ \text { FIT(1)PATOLOGI } & \text { Halaman } 168-174 \\ \text { I N DON E I A } & \text { DOI: } 10.14692 / \text { jfi. } 13.5 .174 \\ \text { ISSN: } 0215-7950 & \end{array}$

\title{
Evaluasi Resistensi Progeni Anggrek Phalaenopsis terhadap Penyakit Busuk Lunak (Pseudomonas viridiflava)
}

\author{
Evaluation of Phalaenopsis Progenies Againts Soft Rot Bacterial \\ Disease (Pseudomonas viridiflava)
}

\author{
Hanudin*, Indijarto Budi Rahardjo, Kurniawan Budiarto
}

Balai Penelitian Tanaman Hias, Cianjur, 43253.

\begin{abstract}
ABSTRAK
Penyakit busuk lunak yang disebabkan oleh Pseudomonas viridiflava merupakan salah satu permasalahan utama di pembibitan anggrek, terutama Phalaenopsis. Evaluasi progeni yang berasal dari 3 kombinasi silangan dilakukan untuk menelaah karakteristik gejala dan perkembangan infeksi penyakit tersebut, serta respons ketahanan progeni terhadap infeksi buatan $P$. viridiflava. Penelitian dilakukan di rumah kaca standar untuk Phalaenopsis yang melibatkan 31 populasi individu dari 3 kombinasi persilangan(P.157, E.2153, dan E.2189). Hasil penelitian menunjukkan bahwa karakteristik gejala infeksi P. viriflava pada daun ditandai oleh peluruhan (lesio) pada jaringan yang diinokulasi. Pada kebanyakan aksesi, lesio membesar dan bau busuk terdeteksi sebagai indikasi keberhasilan infeksi patogen tersebut. Tiga aksesi Phalaenopsis diklasifikasikan ke dalam genotipe resisten (P.157-12, P.157-45, dan P.157-71), sedangkan satu aksesi (P.157-32) dikategorikan sebagai rentan dan 27 aksesi lainnya tergolong genotipe yang sangat rentan.
\end{abstract}

Kata kunci: pembibitan anggrek, progeni persilangan, respons ketahanan

\begin{abstract}
A bacterial soft rot disease caused by P. viridiflava was one of problems in orchid nursery, especially Phalaenopsis. An evaluation on progenies derived from three crossing combinations were conducted to find out the symptom characteristic, development of infections of the disease and resistance response of the progenies against artificial infection of $P$. viridiflava. The research was conducted under a standard glass house conditions for Phalaenopsis involving 31 individuals from 3 progeny populations, namely P.157, E.2153 and E.2189. The results showed that symptoms were characterized by the lesion of the leaf tissues. On most accessions, the lesion enlarged and foul odor was detected as an indication of the successful establishment of bacterial infection. Based on the disease severity, three accessions (P.157-12, P.157-45, and P.157-71) had the lowest infections and were classified into resistant genotypes. One accession, i.e. P.157-32 was classified as susceptible and the rest 27 accessions were grouped into very susceptible class.
\end{abstract}

Key words: crossing progeny, orchid nursery, resistant response

*Alamat penulis korespondensi: Balai Penelitian Tanaman Hias, Jalan Raya Ciherang Segunung Pacet. Kotak POS No. 8 Sindaglaya Cianjur, 43253.

Tel: 0263-514148, Faks: 0263-14148, surel : hanudin@pertanian.go.id. 


\section{PENDAHULUAN}

Phalaenopsis adalah salah satu genus tanaman hias yang terdiri atas 50 spesies. Sebagai tanaman hias bernilai ekonomi tinggi, informasi mengenai keragaman genetikanya masih sedikit demikian juga resistensi terhadap hama dan penyakitnya (Chang et al. 2009).

Busuk lunak bakteri yang disebabkan oleh Pseudomonas viridiflava adalah salah satu masalah pada budi daya anggrek Oncidium, dan Phapiopedilum. Kerusakan akibat patogen ini dapat mencapai 100\% (Hanudin dan Rahardjo 2011).

Perbaikan genetika dari kultivar melalui pemuliaan introgresif adalah salah satu upaya untuk mengatasi masalah penyakit ini. Handayati et al. (2004) melaporkan bahwa tingkat resistensi terhadap infeksi $P$. viridiflava sangat bervariasi antarprogeni. Informasi berkaitan dengan latar belakang genetika, pola pewarisan, proses pemuliaan, dan karakteristik resistensi terhadap $P$. viridiflava pada Phalaenopsis, masih jarang dilaporkan. Penelitian dirancang untuk mengevaluasi resistensi beberapa populasi hasil persilangan tetua Phalaenopsis terhadap $P$. viridiflava dan menelaah gejala karakteristik serangan patogen tersebut.

\section{BAHAN DAN METODE}

Bahan yang digunakan ialah 31 nomor aksesi Phalaenopsis yang berasal dari tiga populasi persilangan. Setiap populasi persilangan terdiri atas 10 atau 11 aksesi (Tabel 1). Aksesi Phalaenopsis merupakan koleksi Bagian Pemuliaan dan Plasma Nutfah, Balai Penelitian Tanaman Hias (Balithi).

Enam bulan setelah dikeluarkan dari botol, individu tanaman dengan jumlah daun sebanyak 6-7 helai ditanam dalam pot plastik berdiameter $20 \mathrm{~cm}$ yang berisi campuran pakis arang kayu. Tanaman dipelihara di rumah kaca dan ditutup dengan jaring polikarbonat yang menyerap cahaya $60 \%$. Cara pemeliharaan berdasarkan standar operasional prosedur budi daya anggrek Phalaenopsis. Pemupukan menggunakan pupuk majemuk NPK 30:30:30 yang dicairkan dengan konsentrasi $0.2 \%$ yang disemprotkan ke daun dengan interval 2 kali dalam seminggu.

\section{Perbanyakan inokulum $P$. viridiflava dan metode inokulasinya}

Galur bakteri $P$. viridiflava $\mathrm{Ph}-7$ merupakan koleksi Laboratorium Bakteriologi Balithi, Cianjur. Bakteri digoreskan pada medium King 'B (20 g proteose peptone No. 3, $10 \mathrm{~g}$ gliserol, $1.5 \mathrm{~g} \mathrm{~K}_{2} \mathrm{HPO}_{4}, 1.5 \mathrm{~g} \mathrm{MgSO}_{4}-7 \mathrm{H}_{2} \mathrm{O}$, $15.0 \mathrm{~g}$ agar-agar dan $100 \mathrm{~mL}^{-1}$ akuades) dan diinkubasikan dalam inkubator bersuhu $32 \pm 2{ }^{\circ} \mathrm{C}$ selama 24 jam. Biakan murni dengan warna koloni hijau berpendar disuspensikan dalam akuades steril sebagai sumber inokulum dengan kerapatan $5.2 \times 10^{10} \mathrm{cfu} \mathrm{mL}^{-1}$.

\section{Inokulasi $P$. viridiflava pada Anggrek}

Setiap aksesi anggrek diinokulasi berdasarkan metode pin pricking (Hanudin dan Rahardjo 2011). Sebanyak dua helai daun (sebagai ulangan), yaitu pada daun ke-3 dan ke-4 dari pucuk dilukai menggunakan jarum semprit hipodermik (berdiameter $0.6 \mathrm{mM}$ ) kemudian diinokulasikan $P$. viridiflava dengan menempelkan kapas steril yang sebelumnya dicelupkan ke dalam suspensi inokulum. Sebagai kontrol digunakan Phalaenopsis aksesi rentan (M22-235) yang dilukai dan ditempeli kapas basah steril tanpa $P$. viridiflava.

Peubah yang diamati meliputi gejala penyakit, waktu inkubasi (WI) dan keparahan penyakit (KP). Keparahan penyakit dihitung menggunakan rumus sebagai berikut:

$$
\mathrm{KP}=\frac{\sum_{\mathrm{i}=0}^{i}\left(\mathrm{n}_{i} \times \mathrm{v}_{i}\right)}{\mathrm{N} \times \mathrm{V}} \times 100 \% \text {, dengan }
$$

$\mathrm{n}_{\mathrm{i}}$ jumlah tanaman dengan skor ke-i; $\mathrm{v}_{\mathrm{i}}$, nilai skala dari tiap kategori serangan (Tabel 1); $\mathrm{N}$, jumlah tanaman yang diamati; dan $\mathrm{V}$, skor tertinggi.

Gejala busuk lunak dinilai berdasarkan skala deskriptif ordinal mulai dari 1-9: 1, tidak ada lesio di lokasi inokulasi; 2, lesio lebih kecil dari $5 \mathrm{~mm}$; 3, lesio antara 5-10 mm; 4, lesio yang lebih besar dari $10 \mathrm{~mm}$ tetapi tidak mencapai batang; 5, lesio mencapai batang utama; 6, infeksi mencapai batang 
Tabel 1 Daftar tiga populasi aksesi Phalaenopsis hasil persilangan yang digunakan pada penelitian

\begin{tabular}{|c|c|c|}
\hline \multicolumn{3}{|c|}{ Kombinasi tetua silangan Phalaenopsis } \\
\hline $\begin{array}{l}\text { "Vulcan Harbour" x ("Golden } \\
\text { Amboin" x "Meller Gold") } \\
\text { (E.2189, nomor kode populasi) }\end{array}$ & $\begin{array}{l}\text { 'Kenanga' x ('Golden Wish’ x } \\
\text { 'Brother Lawrence' } \\
\text { (E.2153, nomor kode populasi) }\end{array}$ & $\begin{array}{l}\text { 'Barbara Moller' x ('Robert } \\
\text { Chick' x 'Golden Amboin') } \\
\text { (P.157, nomor kode populasi) }\end{array}$ \\
\hline 42 & 6 & 3 \\
\hline 43 & 13 & 11 \\
\hline 47 & 14 & 12 \\
\hline 48 & 15 & 17 \\
\hline 49 & 17 & 21 \\
\hline 50 & 18 & 32 \\
\hline 51 & 19 & 35 \\
\hline 52 & 20 & 38 \\
\hline 53 & 21 & 45 \\
\hline 54 & 24 & 71 \\
\hline & 26 & \\
\hline
\end{tabular}

tapi tidak pada daun yang tidak diinokulasi; 7, infeksi mencapai batang dan daun yang tidak diinokulasi; 8 , seluruh batang dan daun terinfeksi tetapi belum mati; dan 9, tanaman mati (Ren et al. 2001).

Waktu inkubasi diamati setiap hari mulai satu hari setelah inokulasi(HSI) sampai seluruh daun yang diinokulasi terinfeksi busuk lunak. Kriteria resistensi ditetapkan menggunakan metode da Silva Felix et al. (2014) yang dimodifikasi pada kriteria ketahanan menjadi, yaitu imun, $\mathrm{KP}=0 \%$; resisten, $1.0<\mathrm{KP}<$ $10 \%$; rentan, $11 \%<\mathrm{KP}<60 \%$; dan sangat rentan, $\mathrm{KP} \geq 61 \%$.

\section{HASIL}

\section{Perkembangan gejala penyakit oleh $P$. viridiflava}

Secara umum awal serangan $P$. viridiflava pada daun Phalaenopsis ditandai dengan bercak hijau kecokelatan yang berkembang menjadi pembusukan jaringan (Gambar 1a). Pada individu tanaman populasi aksesi Phalaenopsis E.2153, gejala pembusukan yang meluas ke seluruh bagian daun dan bagian tanaman lain terdeteksi lebih cepat daripada populasi aksesi Phalaenopsis P.157 dan E.2189 (Tabel 2). Gejala busuk ini menimbulkan aroma yang menyengat. Tanaman dengan gejala seperti ini umumnya mati pada 12 HSI. Inokulasi yang tidak berkembang tampak pada aksesi Phalaenopsis P.157 yang tahan (Gambar 1b).

\section{Keparahan Penyakit dan Klasifikasi Resistensi}

Perkembangan gejala infeksi $P$. viridiflava pada setiap aksesi anggrek yang diuji bervariasi. Pada seluruh progeni pada populasi aksesi Phalaenopsis E.2153, E.2189 dan sebagian besar P.157 yang diuji menunjukkan tingkat perkembangan penyakit dan keparahan yang tinggi. Peningkatan KP paling tajam terlihat pada aksesi E.2153-6, yaitu 3.6, 90.3 dan $100 \%$ pada 1, 3, dan 6 HSI. Pada aksesi P.157-32, tingkat keparahan terdeteksi lebih rendah, yaitu $0.3,3.3,4.6,8.0$ dan $53.4 \%$ pada 1, 3, 6, 9, dan 12 HSI. Tiga aksesi mempunyai tingkat perkembangan infeksi $P$. viridiflava paling rendah dari seluruh tanaman yang diuji, yaitu P.157-12, P.157-45 dan P.157-71 (Tabel 2). Gejala infeksi yang timbul tidak berkembang pada tiga aksesi tersebut hingga 45 HSI, bahkan luka bekas infeksi berubah menjadi kering (Gambar 1b).

Perkembangan dan tingkat keparahan penyakit busuk diklasifikasikan resisten pada tiga aksesi, yaitu P.157-12, P.157-45, dan P.157-71. Aksesi P.157-32 dengan tingkat keparahan tinggi diklasifikasikan rentan dan aksesi lainnya tergolong sangat rentan. 


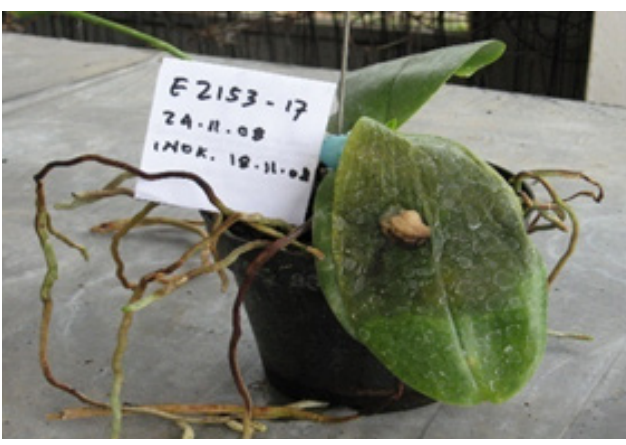

$\mathrm{a}$

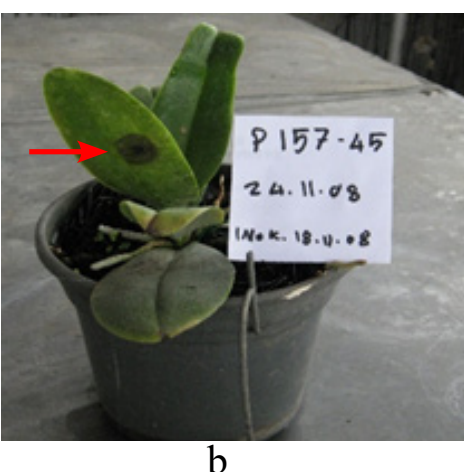

b

Gambar 1 Perkembangan infeksi penyakit busuk lunak Pseudomonas viridiflava. a, Gejala busuk yang meluas ke seluruh bagian daun pada aksesi rentan saat 6 HSI; b, Infeksi tidak berkembang pada aksesi resisten dan gejala penyakit mengering setelah 45 HSI (ditunjukkan dengan panah).

Tabel 2 Perkembangan keparahan penyakit busuk lunak dan resistensi ketahanan penyakit aksesi Phalaenopsis terhadap penyakit busuk lunak

\begin{tabular}{|c|c|c|c|c|c|c|c|}
\hline \multirow[t]{2}{*}{ No aksesi } & \multicolumn{5}{|c|}{ Keparahan penyakit (\%) pada .... HSI } & \multirow{2}{*}{$\begin{array}{l}\text { Waktu inkubasi } \\
\text { (HSI) }\end{array}$} & \multirow{2}{*}{$\begin{array}{l}\text { Ketahanan } \\
\text { penyakit }\end{array}$} \\
\hline & 1 & 3 & 6 & 9 & 12 & & \\
\hline P.157-03 & 7.4 & 77.3 & 100.0 & 100.0 & 100.0 & 1 & Sangat rentan \\
\hline P.157-11 & 0.5 & 28.8 & 66.8 & 100.0 & 100.0 & 1 & Sangat rentan \\
\hline P. $157-12$ & 0.4 & 1.2 & 1.9 & 2.1 & 2.1 & 1 & Resisten \\
\hline P.157-17 & 4.1 & 41.9 & 100.0 & 100.0 & 100.0 & 1 & Sangat rentan \\
\hline P.157-21 & 3.5 & 39.1 & 70.0 & 82.7 & 100.0 & 1 & Sangat rentan \\
\hline P. $157-32$ & 0.3 & 3.3 & 4.6 & 8.0 & 53.4 & 1 & Rentan \\
\hline P.157-35 & 1.0 & 11.1 & 13.4 & 55.9 & 100.0 & 1 & Sangat rentan \\
\hline P. $157-38$ & 1.3 & 33.0 & 69.4 & 100.0 & 100.0 & 1 & Sangat rentan \\
\hline P. $157-45$ & 0.6 & 4.8 & 7.2 & 7.2 & 7.2 & 1 & Resisten \\
\hline P.157-71 & 0.5 & 1.0 & 1.0 & 1.0 & 1.0 & 1 & Resisten \\
\hline E.2153-6 & 3.6 & 90.3 & 100.0 & 100.0 & 100.0 & 1 & Sangat rentan \\
\hline E.2153-13 & 2.5 & 67.7 & 100.0 & 100.0 & 100.0 & 1 & Sangat rentan \\
\hline E.2153-14 & 1.2 & 23.1 & 45.5 & 59.1 & 100.0 & 1 & Sangat rentan \\
\hline E.2153-15 & 3.1 & 49.7 & 100.0 & 100.0 & 100.0 & 1 & Sangat rentan \\
\hline E.2153-17 & 0.8 & 48.2 & 87.2 & 100.0 & 100.0 & 1 & Sangat rentan \\
\hline E. $2153-18$ & 0.9 & 27.2 & 63.8 & 100.0 & 100.0 & 1 & Sangat rentan \\
\hline E.2153-19 & 0.9 & 18.5 & 100.0 & 100.0 & 100.0 & 1 & Sangat rentan \\
\hline E.2153-20 & 9.7 & 35.1 & 100.0 & 100.0 & 100.0 & 1 & Sangat rentan \\
\hline E.2153-21 & 0.2 & 27.9 & 94.9 & 100.0 & 100.0 & 1 & Sangat rentan \\
\hline E.2153-24 & 3.8 & 56.5 & 100.0 & 100.0 & 100.0 & 1 & Sangat rentan \\
\hline E.2153-26 & 0.4 & 26.0 & 41.8 & 100.0 & 100.0 & 1 & Sangat rentan \\
\hline E.2189-42 & 0.2 & 14.5 & 100.0 & 100.0 & 100.0 & 1 & Sangat rentan \\
\hline E.2189-43 & 4.5 & 89.4 & 100.0 & 100.0 & 100.0 & 1 & Sangat rentan \\
\hline E.2189-47 & 2.8 & 71.8 & 100.0 & 100.0 & 100.0 & 1 & Sangat rentan \\
\hline E.2189-48 & 1.8 & 57.0 & 57.2 & 100.0 & 100.0 & 1 & Sangat rentan \\
\hline E.2189-49 & 1.0 & 49.1 & 100.0 & 100.0 & 100.0 & 1 & Sangat rentan \\
\hline E. $2189-50$ & 0.4 & 13.6 & 75.4 & 100.0 & 100.0 & 1 & Sangat rentan \\
\hline E.2189-51 & 1.4 & 58.8 & 94.8 & 100.0 & 100.0 & 1 & Sangat rentan \\
\hline E.2189-52 & 0.8 & 53.6 & 76.7 & 100.0 & 100.0 & 1 & Sangat rentan \\
\hline E.2189-53 & 2.1 & 39.4 & 100.0 & 100.0 & 100.0 & 1 & Sangat rentan \\
\hline E.2189-54 & 1.5 & 61.1 & 100.0 & 100.0 & 100.0 & 1 & Sangat rentan \\
\hline
\end{tabular}

HSI, hari setelah inokulasi 


\section{PEMBAHASAN}

$P$. viridiflava ialah patogen yang memiliki kisaran inang luas. Patogen tersebut dapat menginfeksi tanaman kacang merah (Phaseolus vulgaris), kiwi (Actinidia deliciosa), selada (Lactuca sativa) (Gonzales et al. 2003), wortel (Almeida et al. 2013), kubis (Bhat et al. 2012) dan alfafa (Heydari et. al. 2012) dari bagian daun, batang hingga akar tanaman (Sarris et al. 2012).

Gejala infeksi $P$. viridiflava berupa bercak hijau kecokelatan diikuti pembusukan jaringan. $P$. viridiflava mampu mensekresikan satu set enzim maupun isoenzim yang mendegradasi polimer dinding sel Phalaenopsis (Joko et al. 2014). Bakteri ini dilaporkan mempunyai karakteristik yang sama dengan bakteri penyebab busuk lunak Erwinia dalam mensekresikan 5 isoenzim utama (PelA, PelB, PelC, PelD, PelE) dan 4 isoenzim sekunder (PelI, PelL, PelZ, PelX) pektat liase (Lee et al. 2006). Enzim pektinase merupakan faktor utama patogenisitas bakteri busuk lunak yang digunakan untuk menghancurkan pengikat di antara sel tanaman sehingga menyebabkan kematian jaringan (Mikicinski et al. 2010). Bakteri busuk lunak juga menghasilkan enzim selulase yang berfungsi memecah selulosa yang terdapat pada dinding sel primer dan sekunder tanaman dan enzim protease yang berfungsi untuk merusak protein pada dinding sel sehingga bakteri dapat masuk ke dalam sel tanaman inang (Ismail et al. 2012).

Perkembangan penyakit mencapai $100 \%$ pada 12 HSI pada sebagian besar tanaman yang diuji, walaupun beberapa aksesi menunjukkan respons yang berbeda. Hal ini menunjukkan bahwa galur $P$. viridiflava yang digunakan pada pengujian ini sangat virulen. Perbedaan respons yang ditunjukkan oleh aksesi P.157-12, P.157-45, dan P.157-71 berupa keparahan penyakit yang rendah (1.0$7.2 \%$ pada $12 \mathrm{HSI}$ ) dan gejala infeksi yang mengering hingga 45 HSI mengindikasikan bahwa terdapat mekanisme spesifik yang bersifat endogen pada ketiga aksesi ini yang menyebabkan infeksi $P$. viridiflava tidak dapat berkembang lebih lanjut. Karakteristik ini diduga berhubungan dengan sifat yang diwariskan oleh tetuanya yaitu Phalaenopsis "Barbara Moler", Phalaenopsis "Robert Chick", atau Phalaenopsis "Golden Amboin". Davidsson et al. (2013) melaporkan bahwa resistensi tanaman terhadap penyakit bersifat kompleks dan diatur oleh banyak gen yang dapat diturunkan pada generasi berikutnya.

Secara umum resistensi tanaman terhadap patogen dapat berbentuk resistensi morfologi, anatomi, dan kimia (Henry et al. 2013). Pada resistensi morfologi yang berperan menghambat penetrasi patogen ke dalam jaringan tanaman ialah lapisan epidermis, stomata, dan ketebalan kutikula (Bessire et al. 2007). Lapisan epidermis tebal dilaporkan dapat menghambat infeksi bercak hitam pada mawar (Suhardi dan Winarto 2002); embun tepung pada jeruk (Mahfud 1991); antraknosa pada mangga (Mahfud et al. 1997); dan bercak daun pada pisang (Aliah et al. 2015). Daun yang mempunyai stomata kecil akan menyulitkan penetrasi patogen karat putih pada krisan (Budiarto et al. 2008).

Pada penyakit busuk lunak bakteri, beberapa laporan menyebutkan bahwa mekanisme ketahanan disebabkan oleh karakteristik genotipe tanaman yang mampu memproduksi fitoaleksin yang dapat menghambat atau membunuh patogen (Jeandet et al. 2013). Mekanisme ketahanan tanaman terhadap $P$. viridiflava hingga saat ini belum terungkap sempurna. Marina et al. (2013) melaporkan tingkat resistensi tanaman terhadap infeksi $P$. viridiflava berhubungan dengan meningkatnya konsentrasi poliamine dalam tubuh tanaman. Rossi et al. (2015) juga mengemukakan aktivitas enzim arginine dekarbosilase dapat menghambat patogen $P$. viridiflava.

Berdasarkan perkembangan dan tingkat keparahan penyakit maka aksesi P.157-32 dikategorikan rentan, sedangkan aksesi P.157-12, P.157-45, dan P.157-71 diklasifikasikan resisten. Sebanyak 27 aksesi lainnya yang mempunyai tingkat keparahan penyakit tinggi hingga 12 HSI dikategorikan sangat rentan. Informasi penelitian ini dapat digunakan oleh pemulia dalam studi 
pewarisan sifat ketahanan dan seleksi tetua persilangan Phalaenopsis yang ditujukan untuk mendapatkan progeni resisten terhadap busuk lunak bakteri.

\section{UCAPAN TERIMA KASIH}

Penulis mengucapkan terima kasih kepada Balitbangtan, Puslitbang Hortikultura dan Balai Penelitian Tanaman Hias yang telah membiayai pelaksanaan penelitian. Penulis mengucapkan terima kasih juga kepada Saepullah, Ridwan Daelani, Asep Syamsudin, dan Iman Taufiq yang telah membantu dalam persiapan penelitian dan pengumpulan data selama penelitian berlangsung.

\section{DAFTAR PUSTAKA}

Aliah NU, Sulistyowati L, Muhibbudin A. 2015. Hubungan ketebalan lapisan epidermis daun terhadap serangan jamur (Mycosphaerella musicola) penyebab penyakit bercak daun sigatoka pada sepuluh kultivar pisang. JHPT. 3(1):35-43. Almeida IMG, Maciel KW, Neto JR, Beriam L. 2013. Pseudomonas viridiflva in imported carrot seeds. Aus Plant Dis. 8:17-19. DOI: https://doi.org/10.1007/s13314-012-0086-2.

Bessire M, Chassot C, Jacquat AC, Humphry M, Borel S, Petetot JMC, Metraux JP, Nawrath C. 2007. A permeable cuticle in Arabidopsis leads to a strong resistance to Botrytis cinerea. The EMBO Journal. 26(8):2158-2168. DOI: https://doi. org/10.1038/sj.emboj.7601658.

Budiarto K, Rahardjo IB, Suhardi. 2008. Seleksi ketahanan klon-klon harapan krisan terhadap penyakit karat. J Horti. 18(3):249-254.

Bhat KA, Bhat NA, Mohiddin FA, Sheikh PA, Wani AH. 2012. Studies on pectinase activities of isolates of Erwinia carotovora and Rhizopus sp. causing soft rot in cabbage (Brassica oleracea var. capitata L.). Afric J Agric Res. 7(45):6062-6067. DOI: https://doi.org/10.5897/AJAR12.1215.

Chang YK, Veilleux RE, Iqbal MJ. 2009. Analysis of genetic variability among
Phalaenopsis species and hybrids using amplified fragment length polymorphism. J Am Soc Hort Sci. 134 (1):58-66.

Davidsson PR, Kariola T, Niemi O, Palva ET. 2013. Pathogenicity of and plant immunity to soft rot pectobacteria. Front Plant Sci. 4(191):1-13. DOI: https://doi. org/10.3389/fpls.2013.00191.

Da Silva Felix KC, de Oliveira WJ, Mariano RLR, de Souza EB. 2014. Lettuce genotype resistance to 'soft rot' caused by Pectobacterium carotovorum subsp. carotovorum. Sci Agri. 71(4):287-291. DOI: https://doi.org/10.1590/01039016=2013-0301.

Gonzales AJ, Rodicio MR, Mendoza MC. 2003. Identification of an emergent and atypical Pseudomonas viridiflava lineage causing bacteriosis in plants of agronomic importance in a Spanish Region. App Environ Microbiol. 69(5):29362941. DOI: https://doi.org/10.1128/ AEM.69.5.2936-2941.2003.

Hanudin, Rahardjo IB. 2011. Karakteristik Pseudomonas viridiflava: penyebab penyakit busuk lunak dan evaluasi virulensinya pada klon anggrek Phalaenopsis. JHPT Tropika. 11(2):185193. DOI: http://dx.doi.org/10.23960/j. hptt.211185-193.

Handayati W, Hanudin, Soedjono S. 2004. Resistensi genotip anggrek Phalaenosis terhadap penyakit busuk lunak. J Hort. 14(Edisi khusus):398-402.

Henry E, Yadeta KA, Coaker G. 2013. Recognition of bacterial plant pathogens: local, systemic and transgenerational immunity. New Phytologist. 199:908-915. DOI: https://doi.org/10.1111/nph.12214.

Heydari A, Khodakaramian G, Zafari D. 2012. Characterization of Pseudomonas viridiflava causing alfalfa root rot disease in Hamedan province of Iran. J Plant Pathol Microbiol. 3:135. DOI : https://doi. org/:10.4172/2157-7471.1000135.

Ismail ME, Abdel_Monaim MF, Mostafa YM. 2012. Identification and pathogenicity of phytopathogenic bacteria associated with soft rot disease of girasole tuber in Egypt. 
J. Bacteriol. Res. 4(1):1-8. DOI: https:// doi.org/10.5897/JBR11.015.

Jeandet P, Clément C, Courot E, Cordelier S. 2013. Modulation of phytoalexin biosynthesis in engineered plants for disease resistance. Int J Mol Sci. 14:1413614170. DOI: https://doi.org/10.3390/ ijms140714136.

Joko T, SubandiA, Kusumandani W, WibowoA, Priatmodjo A. 2014. Activities of plant cell wall-degradating enzymes by bacterial soft rot of orchids. Archived Phytopathol Plant Protec. 47(10):1239-1250. DOI: https:// doi.org/ 080/03235408.2013.838374.

Lee YA, Chen KP, Hsu YW. 2006. Characterization of Erwinia chrysanthemi, the soft-rot pathogen of white-flowered calla lily, based on pathogenicity and PCRRFLP and PFGE analyses. Plant Pathol. 55:530-536. DOI: https://doi.org/10.1111/ j.1365-3059.2006.01392.x.

Marina M, SireraFV, Rambla JL, GonzalezME, Blazquez MA, Carbonell J, Pieckenstain FL, Ruiz OA. 2013. Thermospermine catabolism increases Arabidopsis thaliana resistance to Pseudomonas viridiflava. J Experimen Bot. 64(5):1393-1402. DOI: https://doi.org/10.1093/jxb/ert012.

Mikicinski A, Sobiczewski P, Sulikowska M, Pulawska J, Treder J. 2010. Pectolytic bacteria associated with soft rot of calla lily (Zantedeschia spp.) tubers. Phytopathology. 158(4):201-209. DOI: https://doi.org/10.1111/j.14390434.2009.01597.x.

Mahfud MC. 1991. Ketahanan beberapa jenis jeruk terhadap penyakit embun tepung. $\mathrm{J}$ Hort. 1(2):54-57.

Mahfud MC, Purnomo S, Handoko, Tegopati B, Sugiyarto M. 1997. Perbedaan ketahanan beberapa jenis mangga terhadap penyakit antraknosa. J Hort. 7(1):561-565.

RenJR,PetzoldtR,DicksonMH.2001.Genetics and population improvement of resistance to bacterial soft rot in Chinese cabbage. Euphytica. 117(3):197-207. DOI: https:// doi.org/10.1023/A:1026541724001.

Rossi FR, Marina M, Pieckenstain FL. 2015. Role of arginine decarboxylase (ADC) in Arabidopsis thaliana defence against the pathogenic bacterium Pseudomonas viridiflava. Plant Biol (Stuttg). 17(4):831839. DOI: https://doi.org/10.1111/ plb.12289.

Sarris PF, Trantas EA, Mpalantinaki E, Ververidis F. 2012. Pseudomonas viridiflava, a multi host plant pathogen with significant genetic variation at the molecular level. Plos One. 7(4):e36090. DOI: https://doi.org/10.1371/journal. pone.0036090.

Suhardi, Winarto B. 2002. Resistensi varietas mawar (Rosa hybrida) terhadap penyakit bercak hitam. J Hort. 12(1): 56-63. 